\title{
Influence of Boron and Molybdenum on Growth, Yield and Quality of Cauliflower (Brassica oleracea L. var. botrytis)
}

\author{
Vivek Singh $^{1}$, Amit Kumar Singh ${ }^{1}$, Tushar Raghuvanshi ${ }^{1}$, \\ Maneesh Kumar Singh ${ }^{1 *}$, Vineet Singh $^{2}$ and Umesh Singh' \\ ${ }^{1}$ Department of Botany, Udai Pratap Autonomous College, Varanasi-221002 (U.P.), India \\ ${ }^{2}$ Division of Crop Improvement, Indian Institute of Vegetable Research, PB- 01, PO- Jakhini \\ (Shahanshahpur), Varanasi- 221305 (U.P.), India \\ *Corresponding author
}

\begin{tabular}{|c|c|}
\hline \multicolumn{2}{|r|}{ A B S T R A C T } \\
\hline & \multirow{7}{*}{$\begin{array}{l}\text { A field experiment was conducted during the winter season of the year } 2012-13 \text { to assess } \\
\text { the efficacy of various levels of boron and molybdenum on growth, yield and quality of } \\
\text { cauliflower (Brassica oleracea L. var. botrytis). The treatments comprised with foliar } \\
\text { application of boron @ } 100 \mathrm{ppm} \text { and molybdenum @ } 50 \mathrm{ppm} \text { alone and in combination } \\
\text { and two levels of borax @ } 10 \text { and } 20 \mathrm{~kg} / \mathrm{ha} \text { and sodium molybdate @ } 1 \text { and } 2 \mathrm{~kg} / \mathrm{ha} \text { alone } \\
\text { and in combination. The control treatment (NPK @ } 120: 60: 60 \mathrm{~kg} / \mathrm{ha} \text { ) was also laid out. } \\
\text { There were quadratic responses of curd yield, plant weight and plant boron uptake to the } \\
\text { applied boron; quadratic response of plant molybdenum uptake to the applied molybdate, } \\
\text { while the responses of curd yield, and plant weight to the applied molybdenum were } \\
\text { linear. Highly significant positive correlations between curd yield and leaf boron content } \\
\text { as well as curd yield and plant molybdenum content were observed. In conclusion, among } \\
\text { the various treatments, the combined application of borax } 20 \mathrm{~kg} / \mathrm{ha} \text { and sodium molybdate } \\
2 \mathrm{~kg} / \mathrm{ha} \text { as soil application in combination of recommended dose of NPK @ } 120: 60: 60 \\
\mathrm{~kg} / \mathrm{ha} \text { (T12) gave the maximum height of the plant, length of leaf, width of leaf, total } \\
\text { weight of plant, width of curd, average weight of curd and curd yield. }\end{array}$} \\
\hline & \\
\hline & \\
\hline $\begin{array}{l}\text { Quality, Curd yield, } \\
\text { Borax. }\end{array}$ & \\
\hline Article Info & \\
\hline $\begin{array}{l}\text { Accepted: } \\
27 \text { September } 2017 \\
\text { Available Online: } \\
10 \text { October } 2017\end{array}$ & \\
\hline & \\
\hline
\end{tabular}

\section{Introduction}

Cauliflower (Brassica oleracea L. var. botrytis) is a biannual and the herbaceous vegetable crop belongs to the family Cruciferae. It is one of the popular economically winter vegetables in India. Cauliflower thrives very well in a cool- moist climate and it does not withstand very low temperature or too much heat (Din et al., 2007). In India at present cauliflower is growing in almost all the states but mostly grown in Uttar Pradesh, Bihar and Karnataka. It is used as a cooked vegetable, as soups, pickles, drying and also curries etc. Cauliflower is a heavy feeder and it requires large amount of macronutrients as well as micronutrient for better development of curd and its quality. In addition to checking the various diseases and physiological disorders, the use of chemical fertilizers is one of the well-known constrain for maximization of crop yield through their proper utilization. The application of optimum dose of nitrogenous, phosphatic and potassic fertilizers along with some micro-nutrient viz, 
boron and molybdenum are also essential for higher production, better quality and control of nutritional disorders in cauliflower. Plant grown on micro-nutrient deficient soils can exhibit a similar reduction in plant growth and yield as macro- nutrients.

Cauliflower has a high micro-nutrients requirement, particularly boron and molybdenum. Boron is very important for growth and development of cauliflower and is involved in cell division and hence helps in root elongation and shoot growth. It is associated with several physiological processes such as calcium metabolism, auxin synthesis, sugar metabolism translocation of solutes and protein synthesis. Boron plays an essential role in the development and growth of cell in the plant meristem. Since it is not readily translocated from old to actively growing tissues, the first visual deficiency symptoms are cessation of terminal bud growth, leaves are curled, lathery and less in number followed by the death of young leaves. Boron deficiency symptoms appear at the initial stage as water soaked areas developed in the center of the curd and in advanced stage the stem becomes hollow with the cavity surrounded by water soaked tissues. Later curd change to rusting brown, bitter in taste and become rotten. Mehrotra and Mishra (1974) reported that the curd formation was delayed, which turned dirty pale to brown in colour due to deficiency of boron in cauliflower.

Molybdenum is also very essential micronutrient for the better growth and development. It is an essential component of major enzyme nitrate reductase in the plant. It occurs in envelops of chloroplast in leaves.

Cauliflower responds severely to the deficiency of molybdenum and the damage may be considerable. Young cauliflower plant deficient in molybdenum becomes chlorotic and may turn white particularly along the leaf margins. They also become cupped and wither, eventually. The leaf dies and the growing point also collapses. In older plants the lamina of the newly formed leaves are irregular in shape frequently consisting of only a large bare midrib and hence the common name "whiptail; originated. In a field experiment, the application of molybdenum (80or $160 \mathrm{~g} / \mathrm{ha}$ ) increased cauliflower yield by $7-8 \%$ over the control (Joggi and Dixit, 1995). Hunashikatti et al., (2000) reported that the combined application of $25 \mathrm{~kg}$ sulphur and 1 $\mathrm{kg}$ molybdenum /ha produced the maximum yield with a reasonable amount of ascorbic acid $(49.12 \mathrm{mg} / 100 \mathrm{~g})$.

Keeping these facts in view, the present investigation was planned to generate scientific information on influence of boron and molybdenum on growth yield and quality parameter of cauliflower.

\section{Materials and Methods}

The experiment was conducted during the winter season of 2012-13 at the main experimental field department of horticulture, Post Graduate College, Ghazipur. The crop received $337.9 \mathrm{~mm}$ and $65.4 \mathrm{~mm}$ total rainfall, whereas the mean maximum air temperature was $35.2{ }^{\circ} \mathrm{C}$ and $35.4{ }^{\circ} \mathrm{C}$ and minimum was $12.0{ }^{\circ} \mathrm{C}$ and $7.2{ }^{\circ} \mathrm{C}$ during crop period. The initial soil samples were collected from the experimental field to a depth of 0-15 $\mathrm{cm}$ prior to application of fertilizers. The nutrient status of soil of the experimental plot was determined in the Soil Science Lab and found that it was sandy loam with sufficient organic matter, well drained with $\mathrm{pH} 7.40$ and also contain high amount of potash and medium amount of nitrogen and phosphorus.

A pre-irrigation was given to the field before ploughing and soil was pulverized by ploughings followed by planking. Farm yard 
manure at the rate of $20 \mathrm{t} / \mathrm{ha}$ was incorporated in the field at the time of field preparation and common dose of NPK (120:60:60 kg/ha) was given through urea, single super phosphate and muriate of potash. After preparation of layout the 1/3 amount of urea with the full amount of single super phosphate and muriate of potash including borax and sodium molybdate was applied as basal dressing in the hills as per treatment. The fertilizers were mixed thoroughly in the soil. Remaining 2/3 of urea was applied at two split doses at 30 days and 45 days after transplanting as top dressing before earthling was done. The micronutrients i.e. boron and molybdenum were applied as soil applied alone or in combination or as a foliar spray at 20 and 40 days after transplanting as per treatment. In order to keep the field free from weeds, two hands, weedings followed by hoeing were done manually 30 days and 45 days of transplanting.

The seed of cauliflower variety Pusa Hybrid-2 was selected for sowing in well prepared raised bed by opening the miniature furrows at $5 \mathrm{~cm}$ distance. One month old healthy seedlings were lifted carefully and transplanting was done on flat beds at the distance of $60 \times 45 \mathrm{~cm}$. After transplanting the seedling a light irrigation was done. In all, 5 irrigations were given during the crop period. The treatments comprised with foliar application of boron @ 100 ppm and molybdenum @ 50 ppm alone and in combination and two levels of borax @10 and $20 \mathrm{~kg} / \mathrm{ha}$ and sodium molybdate @ 1 and $2 \mathrm{~kg} / \mathrm{ha}$ alone and in combination. The control treatment (NPK @ 120:60:60 kg/ha) was also laid out. Boron was applied in the form of borax and molybdenum through sodium molybdate. Foliar sprays of these micronutrients were given 20 and 35 days after transplanting. The observations related to growth and yield parameters were recorded and analyzed (Panse and Sukhatme, 1985).

\section{Results and Discussion}

The observation regarding the height of plant influenced by the application of boron and molybdenum on cauliflower reveled that treatment $\mathrm{T}_{12}$ (Borax $20 \mathrm{Kg} / \mathrm{ha}+$ Sodium molybdate $2 \mathrm{~kg} / \mathrm{ha}$ ) has highest $60.95 \mathrm{~cm}$ plant height, whereas in control it was minimum $51.67 \mathrm{~cm}$ (Figure 1a). The data presented in figure $1 \mathrm{~b}$, clearly indicated that the micronutrients played significant role in directly affecting the number of leaves per plant. The maximum number of leaves per plant was recorded statistically significant with the micronutrient application of Borax $20 \mathrm{~kg} / \mathrm{ha}+$ sodium $1 \mathrm{~kg} / \mathrm{ha}\left(\mathrm{T}_{12}\right)$, which was recorded 21.35 leaves. The minimum number of leaves per plant (16.36) was noticed with control. Micronutrients played a significant role and directly affecting the number of leaves per plant. The observation regarding the fresh weight of leaves per plant again treatment $\mathrm{T}_{12}$ has recorded highest $896.0 \mathrm{~g}$ fresh weight of leaves, whereas lowest weight was under control $810.6 \mathrm{~g}$ (figure1c). From critical evaluation of various treatment effects highest length and width of leaf recorded under treatment $\mathrm{T}_{12}$ (Borax $20 \mathrm{~kg} / \mathrm{ha}+$ sodium molybdenum $2 \mathrm{~kg} / \mathrm{ha}$ ), were $51.85 \mathrm{~cm}$ and $20.24 \mathrm{~cm}$ and minimum was seen under control $44.97 \mathrm{~cm}$ and $13.38 \mathrm{~cm}$ respectively (Figure 1e).

The maximum total weight of plant $1.93 \mathrm{~kg}$ was found with the soil application of borax @ 20kg/ha +sodium molybdate @ 2kg/ha. However, minimum values were recorded under control treatment $\mathrm{T} 1(1.65 \mathrm{~kg}$ ) (figure 1d). The increase in growth characters might be due to particularly the function of boron, which resulted into the precipitation of excess cation, buffer action, maintenance of conducting tissues, which ultimately helped in absorption of nitrogen, however, molybdenum activates a physiological process by stimulating factor in the 
metabolism and growth of the plant. The finding is in accordance with the study carried out by the Ghosh and Hasan (1997) and Maurya et al., (1992) in cauliflower.

Cauliflower having treatment $\mathrm{T}_{12}$ has taken 71.85 days with the shortest period of curd maturity. However, in control 75.43 days required for the maturity of the curd. By examining the width of the curd treatment Borax @ $20 \mathrm{~kg} / \mathrm{ha}+$ Sodium molybdate 2 $\mathrm{kg} / \mathrm{ha}$ ), has resulted curd width of $16.84 \mathrm{~cm}$, which is significantly larger than all other treatment effect. Whereas it was minimized in control $11.81 \mathrm{~cm}$ (Figure 1f). Data pertaining to the average weight of curd influenced by different levels of boron and molybdenum treatments indicates that treatment $\mathrm{T}_{12}$ has recorded $893.3 \mathrm{~g}$ curd weight which is again significantly higher than all other treatment effects. The nearest weight $859.0 \mathrm{~g}$ was under treatment $\mathrm{T}_{11}$ (Borax $20 \mathrm{~kg} / \mathrm{ha}+$ sodium molybdenum $1 \mathrm{~kg} / \mathrm{ha}$ ) and the lowest curd weight was $625.0 \mathrm{~g}$ noticed under control $\mathrm{T}_{1}$ (Figure 1h). Regarding the average weight of pure curd without guard leaves the treatment combination Borax @ $20 \mathrm{~kg} / \mathrm{ha}+$ sodium molybdenum $2 \mathrm{~kg} / \mathrm{ha}$ has produced highest curd weight of $631.3 \mathrm{~g}$, whereas lowest $504 \mathrm{~g}$ was observed in control (Figure 1g).

Fig.1 Effect of boron and molybdenum on yield and quality of Cauliflower 1(a) Plant height (cm), 1(b) Number of leaves per plant, 1(c) Fresh weight of leaves (g), 1(d) Total weight of plant

(g), 1(e) Length \& width of leaf (cm), 1(f) Days to curd weight (g) 1(g) Average pure curd weight $(\mathrm{g}), 1(\mathrm{~h})$ Average weight of curd (g), 1(i) Width of curd (cm), 1(j) Total yield (g)

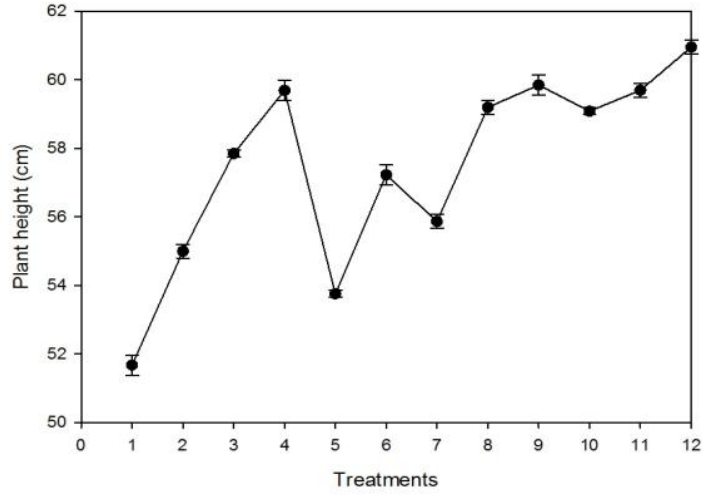

1 (a)

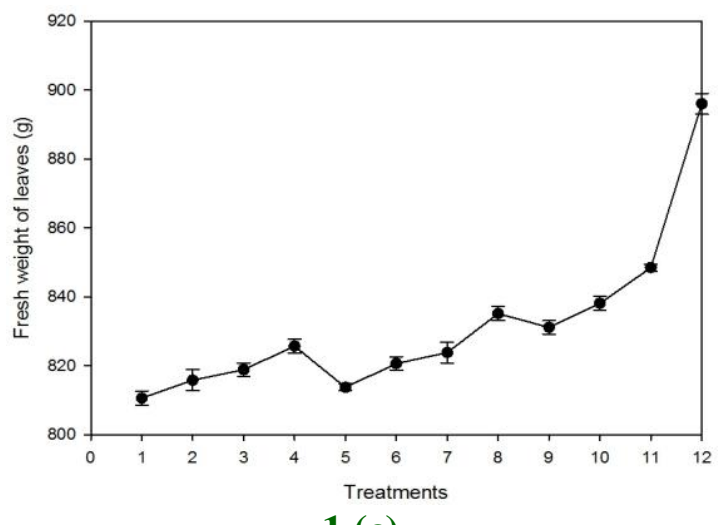

1 (c)

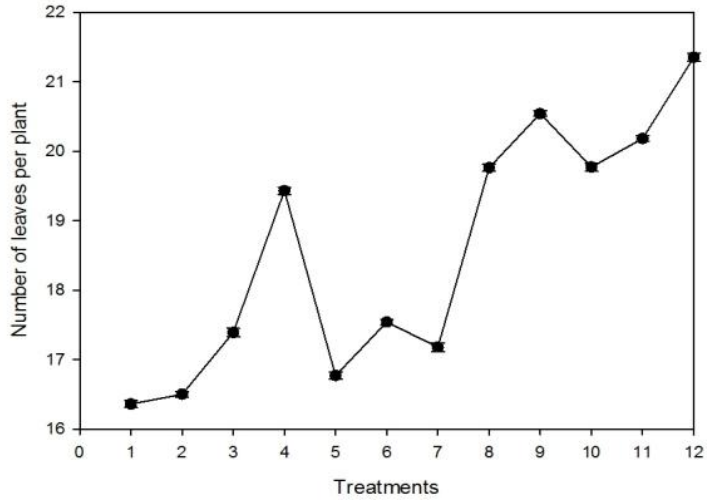

1 (b)

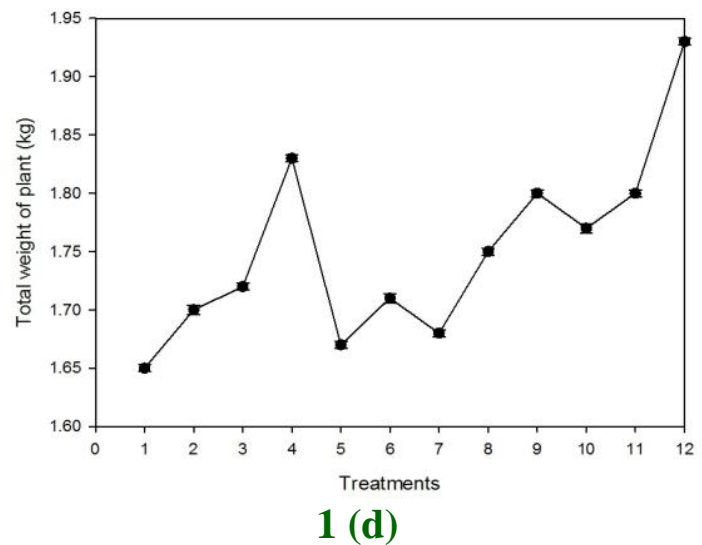




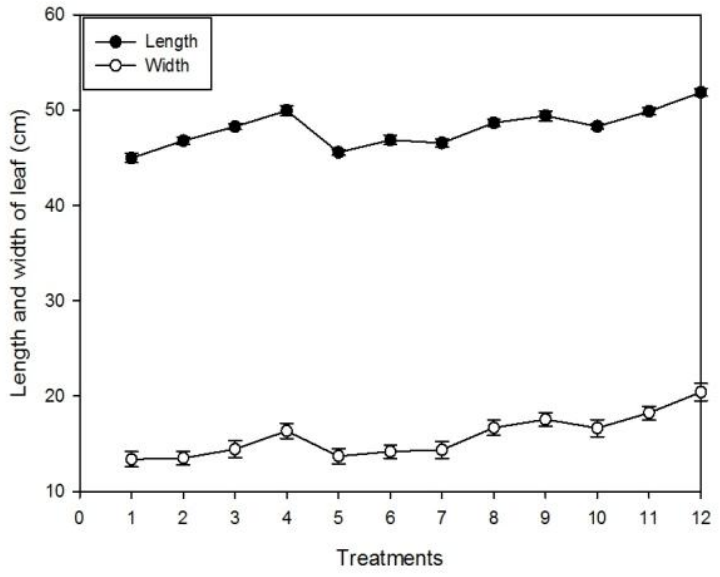

$1(\mathbf{e})$

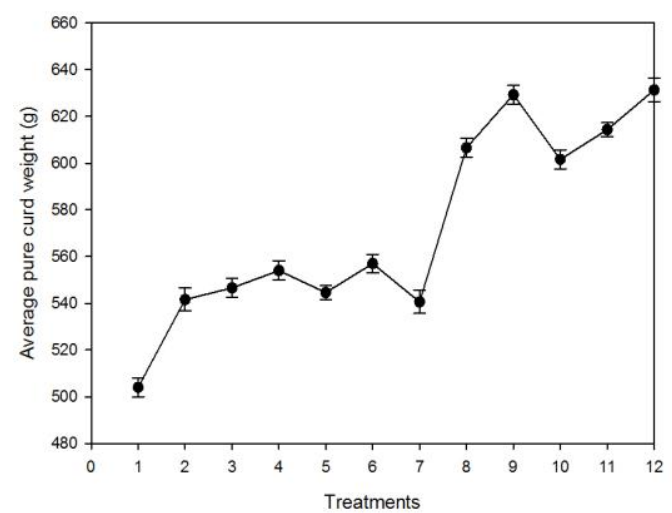

$1(\mathrm{~g})$

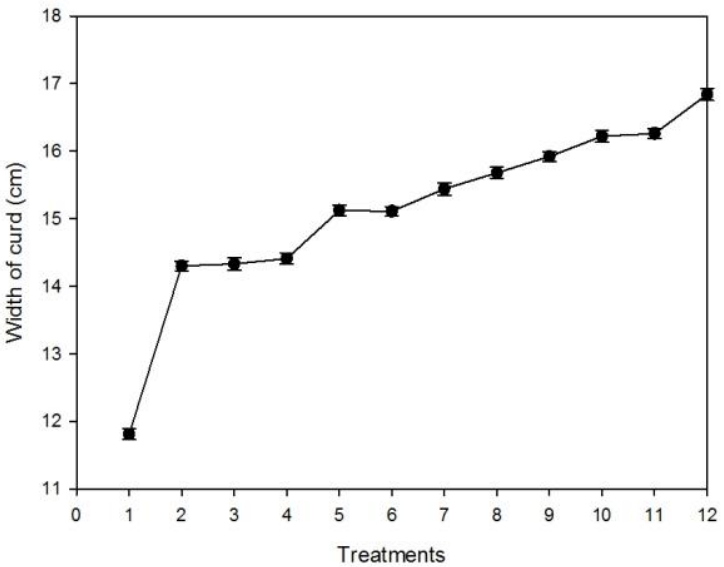

1 (i)

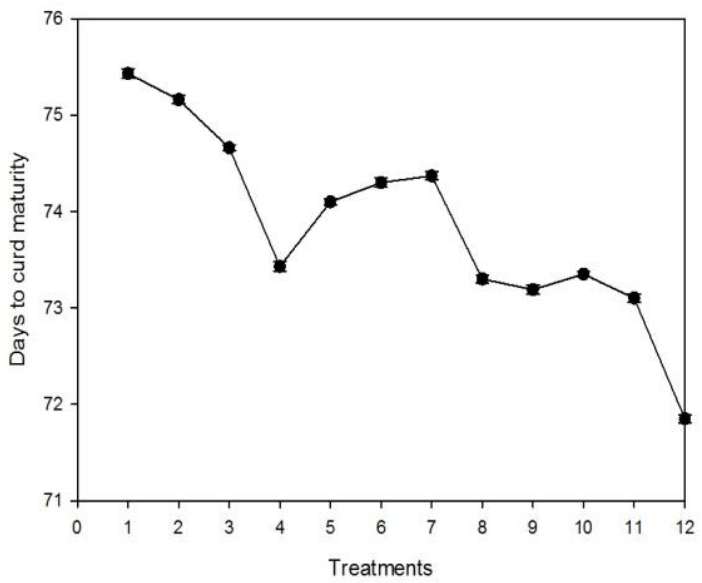

$1(\mathbf{f})$

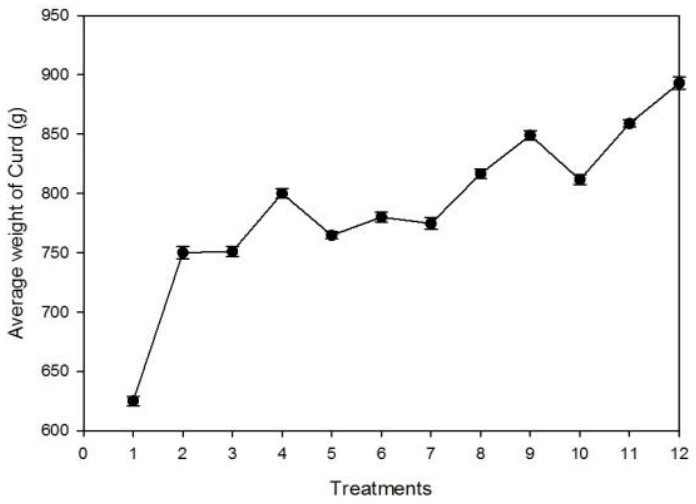

$1($ h)

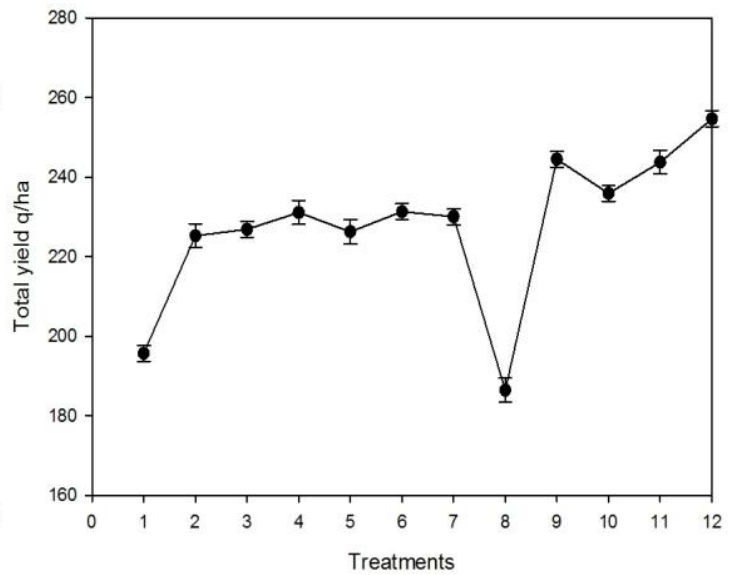

$1(\mathbf{j})$

Whereas, 1-T $\mathrm{T}_{1}$ Control (Rec. dose of NPK@120:60:60 kg/ha), 2-T 2 Boron 100 ppm, 3-T 3 Molybdenum 50 ppm, 4- $\mathrm{T}_{4}$ Boron $100 \mathrm{ppm}$ + Molybdenum $50 \mathrm{ppm}, 5-\mathrm{T}_{5}$ Borax@10 kg/ha, 6- $\mathrm{T}_{6}$ Borax@20 kg/ha, 7-T 7 Sodium molybdate@1kg/ha, 8- $\mathrm{T}_{8}$ Sodium molybdate@2 kg/ha, 9- $\mathrm{T}_{9}$ Borax@10 kg +Sodium molybdate @1 kg/ha, 10- $\mathrm{T}_{10}$ Borax@10 kg + sodium molybdate@2 kg/ ha, 11- $\mathrm{T}_{11}$ Borax@20 kg + sodium molybdate@1 kg/ha, 12- $\mathrm{T}_{12}$ Borax@20 kg + sodium molybdate@2 kg/ha ha 
This increase might be due to the collective effect of boron and molybdenum. Boron plays role in enhancing the translocation of carbohydrates from the site of synthesis to reproductive tissues in the curd, whereas, molybdenum stimulates the photosynthesis and enhance the metabolic process. Such significant response of micronutrients has also been reported by Kotur (1998), Farag et al., (1994), Singh (2003) and Chattopadhyay and Mukhopadhyay (2003) in cauliflower.

Data pertaining to total yield indicates that, treatment $\mathrm{T}_{12}$ has recorded $254.63 \mathrm{q} /$ ha total yield of curd, whereas in control (dose of NPK @ 120: 60: 60 kg/ha) only186.41q/ha average weight of pure curd could be attained (Figure 1j). Increase in yield and quality might be due to the combined application of boron and molybdenum at optimum levels under deficient condition increased uptake of major nutrients which resulted in sturdy plant growth and increased yield and quality. Present result confirms findings of Singh (2003) who found maximum yield with the combined foliar application of boron and molybdenum in cauliflower. In his experiment Borax applied at $5 \mathrm{~kg} \mathrm{ha}^{-1}$ as a soil treatment $+0.25 \%$ as a foliar spray at 45 and 60 DAP resulted in the highest number of leaves per plant (17.4), leaf area $(374.6 \mathrm{~cm} 2)$, curd weight $(510.0 \mathrm{~g})$, curd width $(15.68 \mathrm{~cm})$, curd length $(8.48 \mathrm{~cm})$, curd yield per plot $(16.23 \mathrm{~kg})$, curd yield per ha (140.86 quintal), net profit (51203 rupees/ha) and benefit : cost ratio (4.20). Singh et al., (2002) studied the effect of boron application on cauliflower and reported that soil application of B significantly produced higher marketable curd yields of cauliflower over the control in all three years. Application of B up to $1.0 \mathrm{~kg} \mathrm{ha}^{-1}$ significantly increased the yields.

Prasad and Yadav (2003) also indicated that the effect of foliar application of boron and molybdenum on the growth and yield of cauliflower and found that boron at $0.3 \%$ and molybdenum $0.3 \%$ solution alone and in combination were better than the other treatments (i.e. Boron 0.1 and $0.2 \%$; and molybdenum 0.1 and $0.2 \%$ ) in terms of growth (i.e. Plant height, number of leaves per plant, root length, stem length, stem diameter and plant weight) and yield attributing characters (i.e. Curd height curd weight and curd diameter) over the control.

Thus, it is concluded that the curd yield of cauliflower was the highest at Borax @ 20 $\mathrm{kg} / \mathrm{ha}$ with sodium molybdenum $2 \mathrm{~kg} / \mathrm{ha}$. The experiment showed a significant correlation between boron and molybdenum uptake by plants. Similarly, significant correlation between plant boron with molybdenum uptake and vice versa was also observed. Synergistic interaction could be obtained by applying boron and molybdenum within soil and plant system. It can be recommended that borax $20 \mathrm{~kg} / \mathrm{ha}$ and sodium molybdate $2 \mathrm{~kg} / \mathrm{ha}$ as soil application in combination of recommended dose of NPK @ 120: 60:60 $\mathrm{kg} / \mathrm{ha}$ (T12) is effective in increasing the growth, seed yield and quality of cauliflower.

\section{Acknowledgements}

The authors thank to the research technicians of the research farm for their assistance in field operations.

\section{References}

Chattopadhyay, S.B., and Mukhopadhyay TP 2003. Effect of foliar application of boron and molybdenum on growth and yield of cauliflower in tarai zone West Bengal. Environment and Ecology. 21 (4): 955-59.

Din, F., Qasim M, Elahi N and Faridullah 2007. Responce of different sowing dates on the growth and yield of cauliflower. Sarhad J. Agric. 23(2):289- 
291

Farag, I.A., Faryhali MA, Refai EF and Shalaby GT 1954. Response of two cultivars of cauliflower to nitrogen rates, boron and molybdenum. Assiut. J. Agri. Sci. 25 (5): 221-33.

Ghosh, S.K., and Hasan MA 1997. Effect of boron on growth and yield of cauliflower. Annals of Agril. Res. 18 (3): 391-92.

Hunashikatti, M.G., Channal H J, Sarangamath, PA, Manjunathaiah, H.M and Dharmatti, P. R. 2000. Effect of Sulphur and Molybdenum on yield and quality of cabbage. Fertilizer News, 45 (8): 53-55.

Jaggi, R.C., and Dixit SP, 1995. Response of cauliflower to sulphur and molybdenum in vegetable growing area of Palam Vally. J. of the Indian Society of Soil Sci., 43(2): 229-231.

Kotur, S.C., 1998. Synergistic effect of lime, boron and molybdenum on curd rot and curd yield of cauliflower (Brassica oleracea L. var. botrytis) on Alfisol. Indian J. Agri. Sci. 68 (5): 268-70.

Maurya, A.N., Chaurasia SNS and Reddy
YRM 1992. Effect of nitrogen and molybdenum levels on growth, yield and quality of cauliflower (Brassica oleracea L. var. botrytis) cv. Snowball16. Haryana J. Hort. Sci. 21(3-4): 23235.

Mehrotra, O.N., and PH Mishra. 1974. Prog. Hortic, 5, 33.

Panse, V.G., and Sukhatme PV, 1985. Statistical methods of Agricultural Workers, 5th Ed., ICAR Public. New Delhi.

Prasad, V.M., and Yadav D, 2003. Effect of foliar application of boron and molybdenum on the growth and yield of cauliflower (Brassica oleracea var. botrytis) cv. Snowball-16. New Agriculturist, 14(1/2): 121-122.

Singh, D.N., 2003. Effect of boron on the growth and yield of cauliflower in lateritic soil of Western Orissa. Indian J. Hort., 60 (3): 283-286.

Singh, R.N., Singh S and Karmakar S 2002. Effect of boron application on cauliflower in an acid alfisol. Journal of Research, Birsa Agricultural University. 14(1): 61-63.

\section{How to cite this article:}

Vivek Singh, Amit Kumar Singh, Tushar Raghuvanshi, Maneesh Kumar Singh, Vineet Singh and Umesh Singh. 2017. Influence of Boron and Molybdenum on Growth, Yield and Quality of Cauliflower (Brassica oleracea L. var. botrytis). Int.J.Curr.Microbiol.App.Sci. 6(10): 34083414. doi: https://doi.org/10.20546/ijcmas.2017.610.400 